\title{
Global helse er målet - er helsebistand svaret?
}

Vi har hørt det mange ganger etter tusenårsskiftet - Norge er i toppdivisjonen når det gjelder bistand til helse. Vaksiner til barn og kampen for å sikre kvinner trygge fødsler står i første rekke, mot et bakteppe av solid satsing på hiv/aids og ulike globale helseinitiativer. Statsministeren står i spissen. I motsetning til mange kontroversielle saker som splitter, er helsebistand på noen prioriterte områder blitt noe statsledere trygt kan samarbeide om. Samtidig er det også områder innenfor helse som er konfliktfylte, der land og interesser står mot hverandre og begrenser virkningene av lederskap og penger. På bistandsområdet gjelder det for eksempel patenter og legemiddelpriser, regler for etisk internasjonal rekruttering av helsepersonell, spørsmål knyttet til likestilling, seksuell og reproduktiv helse og kriminalisering assosiert med hivsmitte. Bistand gjennom pengeoverføringer, teknologi og kunnskap er i disse sammenhengene viktig, men ikke nok.

Tidsskriftet publiserte i 2011 en temaserie om global helse (1), i forkant av stortingsmeldingen Global helse i utenriks- og utviklingspolitikken (2). Budskapet er at verden er tettere sammenvevd enn før, slik at stor helseulikhet og ulik mestringsevne gjør alle sårbare. Folkehelse nasjonalt og globalt er avhengig av at alle land i sin samhandling bidrar til helsefremmende nasjonal og internasjonal politikk, basert på deling av kunnskap og ressurser. Det handler om både solidaritet og egeninteresse. Dagens helseutfordringer sprenger rammen for hva nasjonale helsemyndigheter kan ta ansvar for alene, de er knyttet til miljø, pandemier, migrasjon, handel og arbeidsmarked. Internasjonale forhandlinger på disse områdene er krevende, og det er vanskelig å få gjennomslag for løsninger som lar helsehensyn få høy prioritet. Dette krever mer investering i allianser og samarbeid på tvers av regioner og grenser for å finne løsninger på områder der vi nå står fast. Global helse er mer enn helsebistand.

Mange bistandsavhengige land har fortsatt svært svak kapasitet $i$ helsesystemet og står dårlig rustet til å mestre et offentlig ansvar for den nasjonale folkehelsen på lengre sikt. Dette gir betydelig risiko for både nasjonal og global folkehelse. Her er det også på en særlig måte behov for grep for å takle flaskehalser knyttet til global politikk for handel og marked, legemidler og helsepersonell.

Det er nå over store deler av verden stor interesse for å utvikle global helse som fagområde. En rekke universiteter har opprettet egne enheter for området og bruker det som profilering for å tiltrekke seg studenter. En stor og engasjert gruppe medisinstudenter samarbeider internasjonalt om å være pådrivere i globale folkehelsespørsmål og retter oppmerksomheten mot uløste utfordringer som skaper og opprettholder sårbarhet og helseulikhet innenfor og på tvers av land. Nasjonale institusjoner, slik som Folkehelseinstituttet, står i et økende nettverk på kryss og tvers i verden, basert på faglig og likeverdig samarbeid. Det er påfallende at ikke norske helsefaglige miljøer for øvrig har oppdaget dette nye omrisset av utfordrende faglige problemstillinger.

Økende vektlegging av global helse vil få betydning for norsk helsebistand. Frem til tusenårsskiftet ga man støtte til å bygge nasjonale og lokale helsetjenester i mottakerlandene, ofte med norsk personell. Det var rom for et mangfold av aktører, alt fra eksperter og fredskorps til store og små frivillige organisasjoner, misjonshelsetjenester og Leger uten grenser. Internasjonal helse var i stor utstrekning definert av samarbeidet med fattige utviklingsland. Dels handlet det om direkte norsk faglig og økonomisk støtte, dels støtte gjennom FN-systemet, uten at norsk helsebistand var i sentrum for verken utviklings- eller utenrikspolitikk.

Etter tusenårsskiftet har det vært en markert endring. Tusenårsmålene for helse ga muligheter for politisk lederskap og profilering. Kampen mot aids, tuberkulose og malaria fikk egne mål, sammen med barnedødelighet og mødrehelse. Ønsket om raske resultater førte til en rekke nye globale helseinitiativer, med WHO som fødselshjelper og med statsledere og politikere i førersetet. I allianse med hverandre, med FN-organisasjoner og med ledende private aktører har det vært mulig å mobilisere store ressurser og skape stor fremgang. Samtidig har det direkte samarbeidet med hvert land, for eksempel knyttet til grunninvesteringer i nasjonale helsesystemer, fått mindre oppmerksomhet og midler. Denne utviklingen har også gjort at norsk helsepersonell er mindre engasjert i praktisk bistand og at bistandskompetansen har skiftet profil fra helsefag til forvaltning og helsediplomati på globalt nivå.

Et høyt profilert politisk lederskap, slik vi i dag ser for norsk helsebistand og global helse, gir en gjenkjennbar norsk profil internasjonalt og åpner dørene for norsk helsediplomati. Skal det lykkes, kreves det forankring i norsk forvaltning og i norske fagmiljøer som kan bidra med kunnskap, erfaring og nettverk, skape kontinuitet og faglig grunnlag for en samstemt norsk politikk. Mens bistanden hører hjemme i bistandsforvaltningen («Bistands-Norge»), hører helsepolitikken hjemme i helseforvaltningen («Helse-Norge»). Det er ingen samarbeidsfora som regelmessig bringer sammen disse og andre statlige og ikke-statlige aktører av betydning for både bistand og global helse. I Stortingsmelding nr. 11 pekes det på disse utfordringene, men man trekker ingen konsekvenser, verken når det gjelder organisering, finansiering eller kunnskap for en global helsepolitikk (2).

Det er en mangel på sammenheng mellom penger, kunnskap og politikk: Bistandspolitikken handler om pengeoverføringer til fattige land og lite om bruk av norsk kunnskap. Helsepolitikken handler først og fremst om våre nasjonale interesser og prioriteringer og har liten sammenheng med bistands- og utenrikspolitikken. Global helse krever at vi agerer med godt forankret kunnskap, både om helse i fattige land og om helse som angår alle. Nå er kunnskapsmiljøene fragmentert og politikken ikke samstemt. En fortsatt norsk lederrolle i global helse og helsebistand er avhengig av at disse områdene blir bedre samordnet.

\section{Sigrun Møgedal}

sigrun.mogedal@kunnskapssenteret.no

Sigrun Møgedal (f. 1943) er lege og har diplom (DTM\&H) fra London School of Hygiene \& Tropical Medicine. Hun var tidligere norsk ambassadør for aids og globale helseinitiativ, nå er hun pensjonist/spesialrådgiver ved Nasjonalt kunnskapssenter for helsetjenesten.

Forfatter har fylt ut ICMJE-skjemaet og oppgir ingen interessekonflikter.

Litteratur

1. Global helse. http://tidsskriftet.no/tema/globalhelse (8.5.2013).

2. Meld.St. nr. 11 (2011-2012). Global helse i utenriks- og utviklingspolitikken. www.regjeringen.no/nb/dep/ud/dok/regpubl/stmeld/2011-2012/meld-st11-20112012.html?id=671098 (8.5.2013). 